\title{
Diversity of benthic organic matter flows through polychaetes and crabs in a mangrove estuary: $\delta^{13} \mathrm{C}$ and $\delta^{34} \mathrm{~S}$ signals
}

\author{
Hwey-Lian Hsieh ${ }^{1, *}$, Chang-Po Chen ${ }^{1,2}$, Yue-Gau Chen ${ }^{3}$, Hsiao-Hui Yang ${ }^{1,2}$ \\ ${ }^{1}$ Institute of Zoology, Academia Sinica, Nankang Taipei, Taiwan 115, ROC \\ ${ }^{2}$ Institute of Fisheries Science, National Taiwan University, Sec. 4, Rooseveld Road, Taipei, Taiwan 106, ROC \\ ${ }^{3}$ Department of Geology, National Taiwan University, 245 Choushan Road, Taipei, Taiwan 106, ROC
}

\begin{abstract}
Estuaries are biologically diverse systems, especially in the spatial relationships between macrobenthos and their food sources. In a mangrove estuary in northern Taiwan, spatial patterns of organic matter flows from primary producers and detritus derived from vascular plants to macrofaunal polychaetes and crabs were examined using stable isotopes of carbon and sulfur. Sampling was conducted mainly from August 1996 to May 1997 on 2 mud flats, 1 on a tidal creek (Creek site) and the other on a tidal riverbank (River site). The $\delta^{13} \mathrm{C}$ and $\delta^{34} \mathrm{~S}$ ranges at the River site were broader than those at the Creek site $\left(\delta^{13} \mathrm{C}:-28.3\right.$ to $-13.6 \%$ vs -28.3 to $-19.3 \%$, $\delta^{34} \mathrm{~S}: 8.1$ to $15.9 \%$ vs 7.1 to $13.1 \%$ o). This is due to the presence of a C4 plant, the cogon grass Imperata cylindrica at the River site. Although the mangrove Kandelia candel was the largest source of carbon at both study sites, our isotopic analyses showed that it was not as important a source of nutrition to consumers as particulate organic matter (POM), benthic microalgae, and cogon grass. When their $\delta^{13} \mathrm{C}$ and $\delta^{34} \mathrm{~S}$ values were plotted against each other, the $4 \mathrm{crab}$ and 2 polychaete species were differentiated into several distinguishable assemblages which correspond to sites where they reside. The conspecific nereids and fiddler crabs utilize different food sources when inhabiting different sites. Stable isotopic analyses revealed 3 kinds of feeding interactions at the Creek site. Along with detritivory (which uses $\mathrm{POM}$ ) and herbivory (which uses microalgae), carnivory occurs between the grapsid crab Helice formosensis and its sabellid prey. Thus, trophic interactions are more complicated and diverse at the Creek than at the River site where detritivory (using POM plus detritus of cogon grass) is prevalent. A wider range of $\delta^{13} \mathrm{C}$ and $\delta^{34} \mathrm{~S}$ values in a food web does not necessarily mean that the macrobenthos have a greater food variety, nor can one interpret how diverse an estuarine food web is. Instead, the diversity of an estuarine food web is characterized by a series of factors related to spatial differences in flow regimes, the availability and relative contribution of food sources, the opportunistic dietary choices of consumers, and consequently, spatially varying trophic interactions.
\end{abstract}

KEY WORDS: Diversity $\cdot$ Organic matter flow $\cdot$ Polychaete $\cdot$ Crab $\cdot$ Mangrove estuary $\cdot \delta^{13} \mathrm{C} \cdot \delta^{34} \mathrm{~S}$ Resale or republication not permitted without written consent of the publisher

\section{INTRODUCTION}

In estuarine ecosystems, the food web is characterized by the presence of both diverse primary producers and many macrobenthos (Rodelli et al. 1984, Deegan \& Garritt 1997, Kwak \& Zedler 1997). The macrobenthos are provided with food that varies in quantity and

*E-mail: zohl@ccvax.sinica.edu.tw quality, as food sources are often spatially heterogeneous. They exhibit opportunistic feeding and are also capable of assimilating food disproportionately from a common source pool. These characteristics acting together further complicate estuarine food webs (Peterson et al. 1985, Deegan \& Garritt 1997).

In estuaries, food sources of macrobenthos are mainly derived from the fresh and/or degraded products of microalgae, macroalgae, and vascular plants, such as mangroves and marsh plants (e.g. Peterson et 
al. 1986, Sullivan \& Moncreiff 1990, Currin et al. 1995, France 1998). However, the relative importance of algae and vascular plants varies substantially both between and within estuaries. These differences have been attributed to the relative digestibility and productivity of these 2 sources (e.g. Newell et al. 1995, Wainright et al. 2000). Moreover, the relative productivities of phytoplankton, benthic diatoms, and vascular plants are thought to be controlled by tidal mixing processes in a given estuary (Sullivan \& Moncreiff 1990, Deegan \& Garritt 1997). Furthermore, estuaries are generally composed of a network of tidal channels, muddy and sandy intertidal areas, and small embayments; thus they are systems in which the hydrology differs internally. As a result, hydrological parameters not only influence the spatial variability of the food supply to benthic invertebrate consumers, but more importantly may also determine the spatial pattern of trophic relationships and organic matter flows of an estuarine food web.

Studies have demonstrated that many macrobenthos are able to differentiate assimilation of materials from bulk sediments (e.g. Newell et al. 1995, France 1998). In addition, they often feed opportunistically and can change diet in accordance with changes of habitat (e.g. Deegan \& Garritt 1997, Wainright et al. 2000). These abilities allow consumers to exploit different types of food when living in different locations, and subsequently to influence the spatial patterns of trophic relationships in a system.

Previous studies in the Tanshui estuary have shown that in general, nutrient dynamics (Chou \& Bi 1990, Chiu \& Chou 1991), the growth of the mangrove Kandelia candel (Kao \& Chang 1998), and the community structure of polychaetes (Hsieh 1995) differ between mud flats along tidal creeks and tidal riverbanks on the main channel. Among polychaetes, suspension feeders predominantly occur in locations where flow regimes favor particle settling and resuspension as seen at tidal riverbank sites, whereas deposit feeders are more abundant in locations where flow regimes favor particles being bedload transported as seen at creek sites (Hsieh 1995). These results suggest that regions separated by patches of mangrove trees but connected by tidal channels act as if they are different 'microhabitats', and that the food web structure of this estuary as a whole is spatially distinct and complicated.

More strikingly, on the intertidal flats of the Tanshui estuary, the 2 dominant detrital-feeding groups, polychaetes and fiddler crabs, occur in large populations, with densities reaching as high as 19000 and 200 individuals $\mathrm{m}^{-2}$, respectively (Hsieh 1995, Shih 1995). Given such densities, these consumers are likely to interact trophically since both the nereid polychaetes and fiddler crabs reportedly feed mainly on benthic diatoms; however, they also have the capability of tak- ing small living animals (Macnae 1968, Fauchald \& Jumars 1979, Tsuchiya \& Kurihara 1979, Kikuchi \& Wada 1996, Wilson 2000). Nevertheless, studies of food webs in mangrove habitats have mostly focused on the food sources of crabs or economically important species (e.g. Rodelli et al. 1984, France 1998). Currently, there is little understanding as to whether crabs and polychaetes use different food sources and what interrelationships they may have in transferring organic matter in an estuary.

Measurements of stable isotopic ratios of carbon and sulfur have been demonstrated to be a reliable method of tracing linkages between consumers and their potential food sources (e.g. Currin et al. 1995, Wainright et al. 2000). In the present study, we use these natural tracers to examine the food web of the Tanshui mangrove estuary in relation to food utilization by 2 polychaete and $4 \mathrm{crab}$ species. Our objectives include: (1) identifying potential food sources of these macroinvertebrates; (2) elucidating the trophic interactions among these consumers; and (3) characterizing the spatial variability of such trophic relationships.

\section{MATERIALS AND METHODS}

Study area. The study area is located in the Tanshui mangrove estuary in northern Taiwan $\left(25^{\circ} 10^{\prime} \mathrm{N}\right.$, $\left.121^{\circ} 27^{\prime} \mathrm{E}\right)$. Organic matter flows on the intertidal flats were examined at 2 sites, namely the 'Creek' site and 'River' site (Fig. 1). The Creek site is along a shallow creek $(<1.5 \mathrm{~m}$ depth) and is entirely surrounded by the mangrove Kendelia candel. The River site is along the main river channel ( 2 to $12 \mathrm{~m}$ depth), and $K$. candel and several other vascular plant species are distributed along its northern side. The linear distance between the mean high and mean low tidal zones at the Creek site is approximately $8 \mathrm{~m}$, and is $35 \mathrm{~m}$ at the River site. Both tidal flats have very gentle slopes, with an inclination of approximately 1:16 at the River site and an even gentler slope at the Creek site. The sediment substrate at the Creek site consists of fine sand (median grain size diameter $=0.10$ to $0.26 \mathrm{~mm}$ ), whereas that at the River site is mud ( 0.06 to $0.14 \mathrm{~mm}$ ). Salinities at both sites ranged from 2 to $22 \%$ (Hsieh 1995, Hsieh \& Hsu 1999).

Sample collection and preparation. Potential food sources were sampled including particulate organic matter (POM) in the water column carried in with flood tides and freshwater, sedimentary POM, benthic microalgae (mainly diatoms, authors' pers. obs.), filamentous cyanobacteria, and detritus derived from vascular plants. Polychaetes collected were the nereid Neanthes glandicincta and the sabellid Laonome albicingillum; crabs included 3 fiddler crab species, Uca 


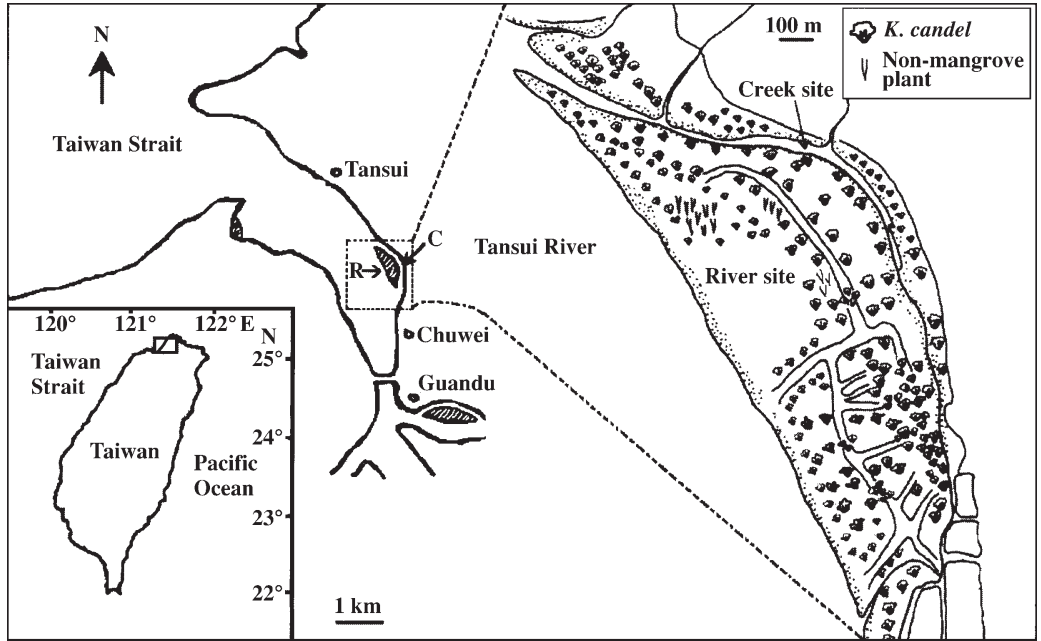

Fig. 1. Map of the Tanshui mangrove estuary in northern Taiwan showing the Creek and River sites

arcuata, $U$. borealis, and U. lactea, and 1 grapsid crab species, Helice formosensis. All samples were collected between 13 and 26 May 1997, except for 4 vascular plant species, the glory bower Clerodendrum inerme, cogon grass Imperata cylindrica, Indian camphor weed Pluchea indica and seep weed Suaeda nudiflora, which were collected in August 1996. Additional cogon grass was collected in September 2000. These collection dates are all in the growing season (March to November) of these plants so that temporal variations of stable isotopic compositions due to plant growth conditions could be minimized. A previous study in the same area also showed that $\delta^{13} \mathrm{C}$ values of the mangrove varied little between years (June 1995 vs May 1998: $-27.4 \%$, W. Y. Kao pers. comm.). In addition, using the natural abundance of stable isotopes of $\mathrm{C}$ and $\mathrm{S}$ provides an integrated measure of assimilated food sources. Therefore, we believe that using data from plants collected at different times will cause no bias and data are thus used in the present study. All samples were kept cold and in the dark during transportation.

Water column POM: For each sampling, 11 of water was taken $30 \mathrm{~cm}$ below the water surface. Between $5 \times$ and $10 \times 11$ samples were collected during flood tides at both sites as well as during ebb tides at the River site. Upon return to the laboratory, water samples were filtered onto precombusted glass fiber filters (GF/C) through a mesh screen (aperture: $40 \mu \mathrm{m}$ ) and then freeze-dried.

Sedimentary POM: Sediment samples were taken from the Creek site and from high, middle, and low tidal elevations at the River site. Each sample was divided into 2 depths, 1 from the upper 0 to $2 \mathrm{~mm}$, and the other from a sediment depth of 2 to $10 \mathrm{~mm}$. Using a mesh screen of $62 \mu \mathrm{m}$ in aperture, sediments at each depth were further separated into 2 size fractions, 1 greater and the other smaller than $62 \mu \mathrm{m}$. Sediment samples were then freeze-dried.

Cyanobacteria, benthic microalgae and vascular plants: Filamentous cyanobacterial mats occurred at the River site. Upon arrival at the laboratory, the cyanobacterial mats were washed vigorously in distilled water to remove extraneous sediments and then freezedried.

The presence of benthic microalgae, mainly diatoms, was obvious at the Creek site where they appeared as a layer of brown coloration on the surface of the sediments. To collect benthic microalgae, sediments at the Creek site were sampled by scraping the surface $2 \mathrm{~mm}$ layer. Within $1 \mathrm{~h}$ of collection, the sediments were brought back to the laboratory where the microalgae were concentrated. Microalgae were separated from bulk sediments following a procedure similar to that described by Riera \& Richard (1996). Subsequently, the microalgae were retained on precombusted glass fiber filters (GF/C) by sieving through a mesh with an aperture of $62 \mu \mathrm{m}$ and then freezedrying. Carbon ${ }^{13} \mathrm{C} /{ }^{12} \mathrm{C}$ compositions of estuarine benthic microalgae (mainly diatoms) average $-17 \%$ as reported from various habitats around the world (e.g. Rodelli et al. 1984, Currin et al. 1995, France 1995). Therefore, the $\delta^{13} \mathrm{C}$ value of benthic diatoms was believed to be distinguishable from that of vascular plants present in this estuary, and the ratios measured from the Creek site were applied to the River site as well.

The mangrove Kandelia candel occurred at both sites, whereas the aforementioned 4 vascular plant species occurred only at the River site near the high tidal zone. Senescent leaves were collected and washed vigorously with distilled water to remove extraneous sediments, then freeze-dried.

Macrobenthos: The nereids and the sabellids occurred at both sites. Individuals at the River site were collected from the middle and low tidal zones as well. After being brought back to the laboratory, the worms were kept alive for $24 \mathrm{~h}$ in filtered water collected from the study area to allow them to evacuate their gut contents. Subsequently, they were washed with distilled water, and whole individuals were freeze-dried and used for stable isotopic measurements.

Specimens of Uca arcuata were available from both sites. U. borealis and Helice formosensis occurred only at the Creek site, whereas U. lactea was available only 
at the River site. Crabs were washed with distilled water, freeze-dried, and only muscle tissue was used for measurement.

Stable isotopic measurement. For $\delta^{13} \mathrm{C}$ measurements, all samples were treated individually. For $\delta^{34}$ S measurements, however, pooled samples were used. Stable isotope ratios are reported in standard notation as: $\delta X(\%)=\left[\left(R_{\text {sample }} / R_{\text {standard }}\right)-1\right] \times 10^{3}$ where $X$ is ${ }^{13} \mathrm{C}$ or ${ }^{34} \mathrm{~S}$ and $R={ }^{13} \mathrm{C} /{ }^{12} \mathrm{C}$ or ${ }^{34} \mathrm{~S} /{ }^{32} \mathrm{~S}$. Mean values are given whenever replicate samples were available. Standard reference materials are PeeDee limestone for carbon and Canyon Diablo meteorite (CDT) for sulfur. Working standard -materials including USGS24 for carbon and NBS127 $\left(\mathrm{BaSO}_{4}\right)$ and laboratory materials against CDT for sulfur were also used. The precision of the measurements was $\pm 0.1 \%$ for $\delta^{13} \mathrm{C}$ and $\pm 0.3 \%$ or for $\delta^{34} \mathrm{~S}$.

$\delta^{13} \boldsymbol{C}$ measurement: All samples were thoroughly ground, acidified with $1 \mathrm{~N} \mathrm{HCl}$ to remove carbonates, rinsed in distilled water, freeze-dried, and ground to powder again. Samples were combusted at $850^{\circ} \mathrm{C}$ in evacuated quartz tubes for $4 \mathrm{~h}$ using $\mathrm{CuO}$ as an oxidant and Ag as a catalyst. The resulting $\mathrm{CO}_{2}$ was purified by a series of cryogenic distillation steps (Hsieh et al. 2000), and its carbon isotope ratio was measured with a mass spectrometer (Finnigan Delta Plus).

$\boldsymbol{\delta}^{34} \boldsymbol{S}$ measurement: To obtain organic sulfur in sedimentary POM, inorganic sulfur substances were removed first. The diffusion methods described by Hsieh \& Yang (1989) and Hsieh \& Shieh (1997) were used. The resultant sediments free of inorganic sulfur were then processed following the Eschka fusion method to extract organic sulfur (ASTM 1974).

Sedimentary POM and tissues of plants and macrobenthos were mixed well with Eschka compound (MgO: $\mathrm{Na}_{2} \mathrm{CO}_{3}=3: 2$ ) in crucibles and combusted at 100,350 and $550^{\circ} \mathrm{C}$ for $24 \mathrm{~h}$, respectively. After combustion, sulfate salts were formed, which were then dissolved by adding boiling deionized water. Boiling was maintained for another $45 \mathrm{~min}$. The hot solution of sulfate salts was centrifuged at $5000 \mathrm{rpm}$ for $15 \mathrm{~min}$, and the supernatant containing $\mathrm{SO}_{4}{ }^{-2}$ was collected. Washing and centrifuging were repeated 3 times. The supernatant was heated again and adjusted to $\mathrm{pH} 3$ with $1 \mathrm{~N} \mathrm{HCl}_{\text {; }}$ then $1 \mathrm{M} \mathrm{BaCl}_{2}$ was added, and $\mathrm{BaSO}_{4}$ was precipitated. Subsequently, $\mathrm{BaSO}_{4}$ was combusted with the oxidants $\mathrm{V}_{2} \mathrm{O}_{5}$ and $\mathrm{SiO}_{2}$ in evacuated quartz tubes at $400^{\circ} \mathrm{C}$ for $5 \mathrm{~min}$ and at $950^{\circ} \mathrm{C}$ for $15 \mathrm{~min}$ (Yanagisawa \& Sakai 1983). Gases produced by combustion below $400^{\circ} \mathrm{C}$ were not collected. The resultant $\mathrm{SO}_{2}$ was then purified by a series of cryogenic distillation steps, and its sulfur isotope ratio was measured with a mass spectrometer (Nuclides).

Statistical analyses. Site, tidal cycle, site/tidal elevation, depth, grain size, and macrobenthos species were the main treatment effects examined. When the as- sumption of homogeneous variances was satisfied, 1-way or 2-way parametric ANOVAs (Sokal \& Rohlf 1981, Hicks 1982) were used. Following a significant ANOVA ( $\mathrm{p}<0.05)$, Duncan's new multiple range comparison was performed to test differences between treatment means. When variances were heterogeneous, a nonparametric 1-way Wilcoxon 2-sample test using a Normal approximation and a 2-way extended Kruskal-Wallis test using a chi-square approximation were performed (Zar 1984). For crabs, only 1-way ANOVA was conducted, due to the distribution of each crab species being site-specific. Statistical calculations were performed using SAS software (SAS Institute 1996).

\section{RESULTS}

\section{$\delta^{13} \mathrm{C}$ and $\delta^{34} \mathrm{~S}$ ranges}

In the $\delta^{13} \mathrm{C}$ continuum, the values at the Creek site ranged from a low of -28.3 to a high of $-19.3 \%$ and at the River site from a low of -28.3 to a high of $-13.6 \%$. In the $\delta^{34} \mathrm{~S}$ continuum, the values at the Creek site ranged from 7.1 to $13.1 \%$ and at the River site from 8.1 to $15.9 \%$. The wider $\delta^{13} \mathrm{C}$ range at the River site was due to the occurrence of the C4 plant Imperata cylindrica (Fig. 2).

\section{$\delta^{13} \mathrm{C}$ of the water column POM}

The $\delta^{13} \mathrm{C}$ values of the water column POM did not differ between the Creek and River sites (-24.8 vs $-24.1 \%$, $\mathrm{p}=0.29$ ), nor between the ebb and flood tides ( -24.6 vs $-24.0 \%$, $\mathrm{p}=0.21$; Table 1$)$.

\section{$\delta^{13} \mathrm{C}$ and $\delta^{34} \mathrm{~S}$ of sedimentary POM}

The $\delta^{13} \mathrm{C}$ value of sedimentary POM was $-25.4 \%$ at the Creek site, whereas those of high, middle, and low intertidal zone sediments at the River site ranged from

Table 1. Comparisons of $\delta^{13} \mathrm{C}$ values of water column particulate organic matter (POM) between site and tidal cycle. ns: not significant

\begin{tabular}{|lrrccl|}
\hline ANOVA & \multicolumn{2}{c}{$\delta^{13} \mathrm{C}$} & \multicolumn{2}{l}{ Result } \\
& $\mathrm{df}$ & $\mathrm{MS}$ & $F$ & $\mathrm{p}$ & \\
\hline Site & 1 & 1.00 & 1.23 & $\mathrm{~ns}$ & Creek = River \\
Error term & 13 & 0.81 & & & \\
Tidal cycle & 1 & 1.37 & 1.75 & $\mathrm{~ns}$ & Flood = Ebb \\
Error term & 13 & 0.78 & & & \\
\hline
\end{tabular}


Table 2. Comparisons of $\delta^{13} \mathrm{C}$ and $\delta^{34} \mathrm{~S}$ values of sedimentary POM between site/tidal elevation, depth, and grain size, and between 2- and 3-factor interactions. High, Middle, and Low indicate high, middle, and low tidal elevations at the River site, respectively. ${ }^{*} \mathrm{p}<0.05,{ }^{* *} 0.05<\mathrm{p}<0.01$, ns: not significant

\begin{tabular}{|c|c|c|c|c|c|c|c|c|c|}
\hline \multirow{2}{*}{ ANOVA } & \multicolumn{4}{|c|}{$-\delta^{13} \mathrm{C}-$} & \multicolumn{4}{|c|}{$-\delta^{34} \mathrm{~S}-$} & \multirow{2}{*}{ Result } \\
\hline & $\mathrm{df}$ & MS & $F$ & $\mathrm{p}$ & $\mathrm{df}$ & MS & $F$ & $\mathrm{p}$ & \\
\hline Site/tidal elevation & 3 & 0.08 & 0.54 & ns & 2 & 1.40 & 26.62 & * & $\begin{array}{l}\delta^{13} \mathrm{C} \text { Creek }=\text { River High }=\text { Middle }=\text { Low } \\
\delta^{34} \text { S River Middle }=\text { Low }>\text { Creek }\end{array}$ \\
\hline Depth & 1 & 0.29 & 2.02 & ns & 1 & 0.83 & 15.81 & ns & $\delta^{13} \mathrm{C}$ Upper $=$ Lower depth \\
\hline Grain size & 1 & 8.85 & 61.26 & ${ }^{* *}$ & 1 & 9.93 & 188.80 & ${ }^{* *}$ & $\delta^{34} \mathrm{~S}$ Upper $=$ Lower depth \\
\hline Site/tidal elevation $\times$ Depth & 3 & 0.13 & 0.92 & ns & 2 & 0.09 & 1.64 & ns & $\delta^{13} \mathrm{C}$ Small > Large grain size \\
\hline $\begin{array}{l}\text { Site/tidal elevation } \\
\times \text { Grain size }\end{array}$ & 3 & 0.03 & 0.19 & ns & 2 & 0.86 & 16.33 & ns & $\delta^{34}$ S Large $>$ Small grain size \\
\hline Depth $\times$ Grain size & 1 & 0.21 & 1.44 & $\mathrm{~ns}$ & 1 & 0.30 & 5.72 & ns & \\
\hline $\begin{array}{l}\text { Site/tidal elevation } \times \text { Depth } \\
\times \text { Grain size }\end{array}$ & 3 & 0.12 & 0.86 & ns & - & - & - & - & \\
\hline Error term & 24 & 0.14 & & & 2 & 0.05 & & & \\
\hline
\end{tabular}

-25.5 to $-25.3 \%$. These $\delta^{13} \mathrm{C}$ ratios did not vary with site/tidal elevations ( $p=0.66$; Table 2 ). However, the $\delta^{34} \mathrm{~S}$ ratios in the middle and low tidal zones at the River site were slightly greater than those at the Creek site (8.0 to 8.2 vs $7.1 \%$, $p=0.04$; Table 2 ).

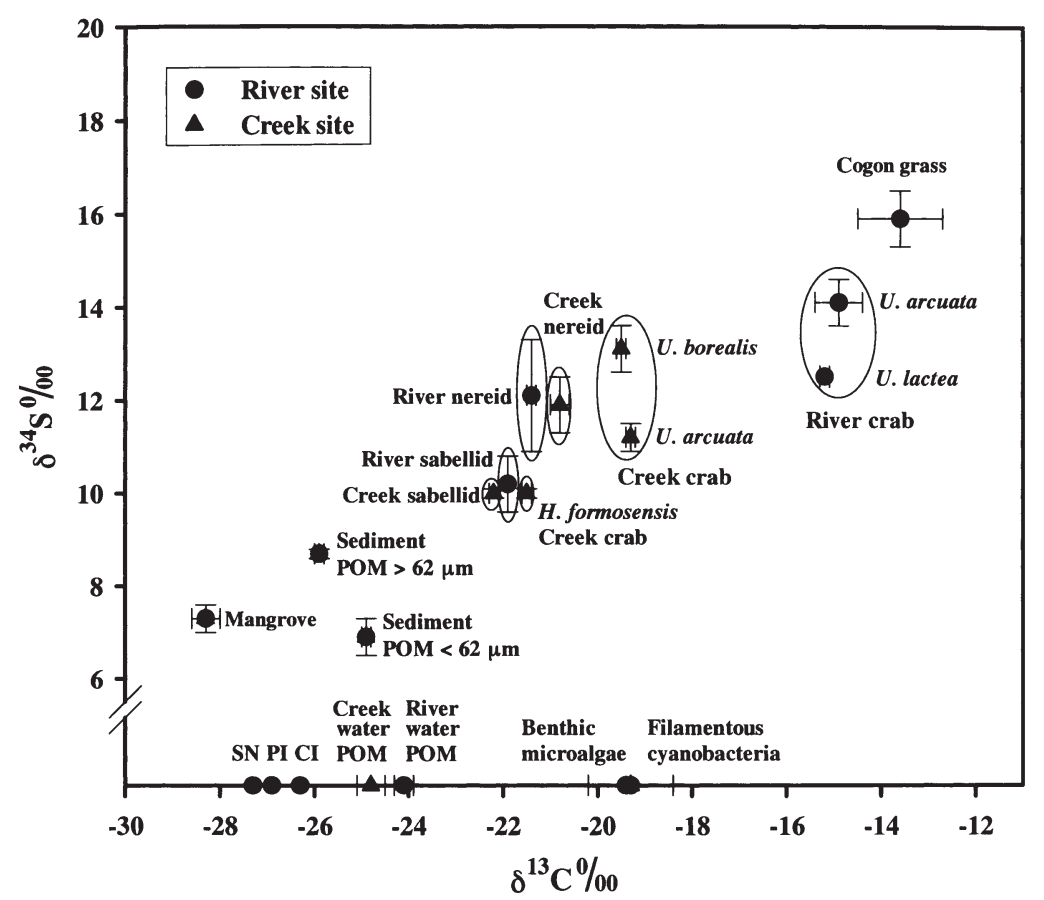

Fig. 2. Dual isotope plots of mean $\delta^{13} \mathrm{C}$ and $\delta^{34} \mathrm{~S}$ values of primary producers, water column and sedimentary POM, nereid and sabellid polychaetes, and fiddler and grapsid crabs from the creek and river sites. Values are shown as mean \pm SE (bars). SN: seep weed, PI: Indian camphor weed, CI: glory bower. Materials with no $\delta^{34} \mathrm{~S}$ values are placed directly on the $x$-axis. The ellipses are drawn to mark macrobenthos assemblages and also for ease of reading
In addition, the $\delta^{13} \mathrm{C}$ and $\delta^{34} \mathrm{~S}$ values of surficial sediments (from 0 to $2 \mathrm{~mm}$ depth) did not differ from those in the 2 to $10 \mathrm{~mm}$ depth range $\left(\mathrm{p}=0.17\right.$ for $\delta^{13} \mathrm{C}$, $\mathrm{p}=0.06$ for $\delta^{34} \mathrm{~S}_{\text {; }}$ Table 2).

By contrast, $\delta^{13} \mathrm{C}$ values of particles larger than $62 \mu \mathrm{m}$ were more depleted than those of smaller particles $(-25.9$ vs $-24.8 \%$, p < 0.01). However, $\delta^{34} \mathrm{~S}$ was more enriched in larger particles (8.7 vs 6.9\%, p < 0.01; Table 2). Interactions between site/tidal elevation, depth, and grain size on both isotopic compositions were all insignificant (2- and 3-factor interactions with $\mathrm{p}>0.05$; Table 2). These results indicate that grain size significantly influenced the $\delta^{13} \mathrm{C}$ and $\delta^{34} \mathrm{~S}$ signatures of sedimentary POM, and that stable isotopic fractionation of organic carbon and sulfur differed for different grain sizes (Fig. 2).

Furthermore, sedimentary POM at both sites exhibited $\delta^{13} \mathrm{C}$ values closer to those of the C3 vascular plant than to those of the filamentous cyanobacteria, benthic microalgae, or C4 plant. These data indicate that the $\delta^{13} \mathrm{C}$ of sedimentary POM is mainly determined by C3 vascular plants (Fig. 2).

\section{$\delta^{13} \mathrm{C}$ and $\delta^{34} \mathrm{~S}$ of primary producers}

$\delta^{13} \mathrm{C}$ values of primary producers exhibited a wide range, from a low of $-28.3 \%$ in Kandelia candel, to a high of $-13.6 \%$ in the C4 plant, cogon grass Imperata cylindrica (Fig. 2). The values recorded in benthic cyanobacteria and microalgae were interme- 
diate $\left(-19.4\right.$ and $-19.3 \%$, respectively). The $\delta^{34} \mathrm{~S}$ values of K. candel averaged 7.3\%, whereas I. cylindrica exhibited a greatly enriched signature of $15.9 \%$ (Fig. 2).

\section{$\delta^{13} \mathrm{C}$ and $\delta^{34} \mathrm{~S}$ of macrobenthos}

When the respective $\delta^{13} \mathrm{C}$ and $\delta^{34} \mathrm{~S}$ values of polychaete and crab species from each site were plotted against each other, the trophic relationships among these animals were well differentiated spatially and taxonomically (Fig. 2).

\section{Polychaetes}

At the River site, the nereids Neanthes glandicincta living in middle and low intertidal zones exhibited no differences in $\delta^{13} \mathrm{C}$ and $\delta^{34} \mathrm{~S}$ values $\left(\delta^{13} \mathrm{C}\right.$ : -21.4 vs $-21.3 \%$, $p=0.38 ; \delta^{34} \mathrm{~S}$ : 13.2 vs $11.0 \%$, $\left.\mathrm{p}=0.47\right)$. The sabellids Laonome albicingillum in the middle intertidal zone had a $\delta^{13} \mathrm{C}$ value statistically greater than that recorded in the low zone $(-21.9$ vs $-22.0 \%$, $\mathrm{p}=0.004$ ), but the small discrepancy is biologically insignificant. Regarding their $\delta^{34} \mathrm{~S}$ values, the sabellids, like the nereids, showed no zonal differences (9.4 vs. $11.1 \%$, $p=0.25$ ).

When data from the 2 intertidal zones were combined, the nereids had a $\delta^{13} \mathrm{C}$ value consistently more enriched than that of the sabellids at both sites $(-21.4$ to -20.8 vs -22.2 to $-21.9 \%$, p < 0.01; Table 3, Fig. 2), but their $\delta^{34} \mathrm{~S}$ values did not differ (11.0 to 13.2 vs 9.4 to $11.1 \%$, $\mathrm{p}=0.11$; Table 3, Fig. 2), indicating a strong species effect on the $\delta^{13} \mathrm{C}$ signature. When the 2 species were combined, the $\delta^{13} \mathrm{C}$ and $\delta^{34} \mathrm{~S}$ values of polychaetes at the Creek site and those at the River site did not differ $\left(\delta^{13} \mathrm{C}\right.$ : $p>0.05, \delta^{34} \mathrm{~S}: \mathrm{p}=0.85$; Table 3$)$, revealing that site alone did not affect the polychaetes' isotopic signatures.

By contrast, species and site significantly interacted with each other in the fractionation of $\delta^{13} \mathrm{C}$ values (effects of species by site, $\mathrm{p}<0.05$; Table 3 ). In which the nereids' $\delta^{13} \mathrm{C}$ values at the Creek site were approximately $0.6 \%$ more enriched than those at the River site ( $p<0.05$; Fig. 2 ), but this between-site difference was reversed in the sabellid situation, where individuals living at the River site had $\delta^{13} \mathrm{C}$ values about $0.3 \%$ more enriched than those at the Creek site $(\mathrm{p}<0.01$; Fig. 2).

\section{Crabs}

At the Creek site, the crabs Uca arcuata and U. borealis did not differ in their $\delta^{13} \mathrm{C}$ values, but differed from Helice formosensis in having a more enriched signature (-19.3 and -19.4 vs $-21.5 \%$, p < 0.01; Table 4, Fig. 2). With regard to $\delta^{34} \mathrm{~S}, U$. borealis had a signature more enriched than those of both $U$. arcuata and $H$. formosensis (13.1 vs 11.2 and $10.0 \%$, p = 0.02; Table 4, Fig. 2), while values for the latter 2 species did not differ from each other. By contrast, at the River site, the $\delta^{13} \mathrm{C}$ and $\delta^{34} \mathrm{~S}$ values of $U$. arcuata and U. lactea did not differ $\left(\delta^{13} \mathrm{C}:-14.9 \mathrm{vs}-15.2 \%\right.$, $\mathrm{p}=0.66 ; \delta^{34} \mathrm{~S}: 14.1 \mathrm{vs}$ $12.5 \%$, $\mathrm{p}=0.54 ;$ Table 4 ).

Uca arcuata and $U$. lactea living at the River site expressed a marked 4 to $6 \%$ onrichment in $\delta^{13} \mathrm{C}$ over those of $U$. arcuata, $U$. borelais, and Helice formosensis living at the Creek site $(\mathrm{p}<0.01$; Table 4$)$. The site effect also distinctly occurred between conspecific individuals as found in $U$. arcuata, in which site differences in $\delta^{13} \mathrm{C}$ were $4.4 \%$ (Fig. 2). However, site effects on the crabs' $\delta^{34} \mathrm{~S}$ values were not significant (Table 4 ).

\section{Assemblages of macrobenthos}

Along the increasing gradient of the six consumers' isotopic signatures in the dual plots of $\delta^{13} \mathrm{C}$ against $\delta^{34} \mathrm{~S}$, the sabellids were most depleted in $\delta^{13} \mathrm{C}$ and could be distinguished as those comprised of a creek

Table 3. Comparisons of $\delta^{13} \mathrm{C}$ and $\delta^{34} \mathrm{~S}$ values of 2 polychaete species Neanthes glandicincta and Laonome albicingillum, between site and species and between 2 -factor interactions. Observed (Obs.) $\chi^{2}=\mathrm{SS} / \mathrm{MS}$, tabulated $\chi^{2}{ }_{0.05(1)}=3.84,{ }^{*} \mathrm{p}<0.05,{ }^{* *} 0.05<\mathrm{p}<$ 0.01, ns: not significant

\begin{tabular}{|c|c|c|c|c|c|c|c|c|c|c|}
\hline \multirow{2}{*}{ ANOVA } & \multicolumn{5}{|c|}{$\delta^{13} \mathrm{C}$} & \multicolumn{4}{|c|}{$\delta^{34} \mathrm{~S}$} & \multirow{2}{*}{ Result } \\
\hline & df & SS & MS & Obs. $\chi^{2}$ & $\mathrm{p}$ & $\mathrm{df}$ & MS & $F$ & $\mathrm{p}$ & \\
\hline Species & 1 & 1995.27 & 77.46 & 25.74 & ${ }^{* *}$ & 1 & 9.41 & 3.22 & ns & $\begin{array}{l}\delta^{13} \mathrm{C} \text { Nereid }>\text { Sabellid } \\
\delta^{34} \mathrm{~S} \text { Nereid }=\text { Sabellid }\end{array}$ \\
\hline Site & 1 & 2.40 & 77.46 & 0.03 & ns & 1 & 0.11 & 0.04 & ns & $\begin{array}{l}\delta^{13} \mathrm{C} \text { Creek }=\text { River } \\
\delta^{34} \mathrm{~S} \text { Creek }=\text { River }\end{array}$ \\
\hline Species $\times$ Site & 1 & 317.4 & 77.46 & 4.09 & $*$ & 1 & 0.001 & 0.00 & ns & $\begin{array}{c}\delta^{13} \text { C Nereid Creek }>\text { River } \\
\text { Sabellid River }>\text { Creek }\end{array}$ \\
\hline Error term & & & & & & 8 & 2.93 & & & $\begin{array}{c}\delta^{34} \text { S Nereid Creek }=\text { River } \\
\text { Sabellid Creek = River }\end{array}$ \\
\hline
\end{tabular}


and a river population. The nereids followed and were more enriched in $\delta^{13} \mathrm{C}$, also displaying characteristics of a river and a creek population (Fig. 2).

With the exception of Helice formosensis, crab populations were more enriched than were polychaete populations. For all crabs, 3 assemblages were readily recognized (Fig. 2). One group consisted of a single species, $H$. formosensis, and was distinguished as a 'Creek crab population' by having $\delta^{13} \mathrm{C}$ and $\delta^{34} \mathrm{~S}$ values lower than those of 'Creek nereids' but higher $\delta^{13} \mathrm{C}$ and similar $\delta^{34} \mathrm{~S}$ values to those of 'Creek sabellids'. Another group consisted of Uca borealis and U. arcuata and was recognized also as a 'Creek crab assemblage' by its moderately enriched ${ }^{13} \mathrm{C}$ and ${ }^{34} \mathrm{~S}$ signatures. The third group consisted of $U$. arcuata and $U$. lactea as a 'River crab assemblage' and was distinguished by its highly enriched ${ }^{13} \mathrm{C}$ and ${ }^{34} \mathrm{~S}$ signatures (Fig. 2).

\section{Potential food sources of the macrobenthos at both sites}

Potential food of a given consumer was determined with the assumption of a 1 to $2 \%$ increment in $\delta^{13} \mathrm{C}$ and almost no fractionation in $\delta^{34} \mathrm{~S}$ during food assimilation (Peterson \& Fry 1987, Hentschel 1998).

\section{Polychaetes}

At both sites, the sabellids' $\delta^{13} \mathrm{C}$ value was 2.3 to $2.6 \%$ more enriched than that of water column POM, but was 2.6 to $2.9 \%$ more depleted than that of benthic microalgae (Fig. 2), indicating that the sabellids utilized the water column POM as their main food source. The Creek nereids' $\delta^{13} \mathrm{C}$ value $(-20.8 \pm 0.2 \%)$ was $4.0 \%$ higher than that of water column POM but closer to the $\delta^{13} \mathrm{C}$ range of the benthic microalgae $(-20.4$ to $-18.3 \%$ ), suggesting that the Creek nereids fed on benthic microalgae. However, the River nereids' $\delta^{13} \mathrm{C}$ value $(-21.4 \pm 0.1 \%$ o was $2.8 \%$ more enriched than that of water column POM and $2.1 \%$ more depleted than that of benthic microalgae, suggesting that River nereids utilized POM from the water column, although a mixed diet of 3 components (POM and 2 algae) would also be possible since the cyanobacterial value was also within the $\delta^{13} \mathrm{C}$ range of the benthic microalgae (Fig. 2).

Although the Creek nereids' $\delta^{13} \mathrm{C}$ value was $1.4 \%$ more enriched than that of Creek sabellids, their $\delta^{34} \mathrm{~S}$ values differed by $1.9 \%$, indicating that the nereids did not feed on sabellids (Fig. 2).

\section{Crabs}

At the Creek site, Uca arcuata and U. borealis had $\delta^{13} \mathrm{C}$ values in the range of those of benthic microalgae, revealing that crabs ate algal materials. However, a mixed diet of algae with sedimentary POM and detritus from cogon grass could also be possible. Contrarily, at the River site, the crabs $U$. lactea and $U$. arcuata had $\delta^{13} \mathrm{C}$ and $\delta^{34} \mathrm{~S}$ values close to those of the $\mathrm{C} 4$ plant Imperata cylindrica, and differed greatly from any other type of primary producers or POM. These data reveal that River crabs utilized this plant species as their main food source (Fig. 2).

By contrast to the Uca crabs, the grapsid crab Helice formosensis had a $\delta^{13} \mathrm{C}$ signature approximately $0.7 \%$ more enriched than that of the sabellids, and its $\delta^{34} \mathrm{~S}$ value was identical to that of these polychaetes. These signatures suggest that this grapsid crab feeds upon this sabellid (Fig. 2).

\section{DISCUSSION}

\section{Diversity of benthic food webs between sites}

The results of the present study clearly reveal a spatially differentiated pattern of organic matter flows in

Table 4. Comparisons of $\delta^{13} \mathrm{C}$ and $\delta^{34} \mathrm{~S}$ values of $4 \mathrm{crab}$ species, Uca arcuata, U. borealis, U. lactea and Helice formosensis, between site and species. $Z$ : normal approximation, ${ }^{*} \mathrm{p}<0.05,{ }^{* *} 0.05<\mathrm{p}<0.01$, ns: not significant

\begin{tabular}{|c|c|c|c|c|c|c|c|c|c|}
\hline \multirow{2}{*}{ ANOVA } & \multicolumn{4}{|c|}{$-\delta^{13} \mathrm{C}-$} & \multicolumn{4}{|c|}{$\delta^{34} \mathrm{~S}$} & \multirow{2}{*}{ Result } \\
\hline & $\mathrm{df}$ & MS & $F$ & $\mathrm{p}$ & df & MS & $F$ & $\mathrm{p}$ & \\
\hline Species at Creek site & 2 & 4.46 & 117.20 & $* *$ & 2 & 4.78 & 21.90 & $*$ & $\begin{array}{l}\delta^{13} \mathrm{C} U . \text { arcuata }=U . \text { borealis } \\
>H . \text { formosensis }\end{array}$ \\
\hline Error term & 6 & 0.04 & & & 3 & 0.22 & & & $\begin{array}{l}\delta^{34} \mathrm{~S} U . \text { borealis }>U . \text { arcuata } \\
=H \text {. formosensis }\end{array}$ \\
\hline Species at River site & \multicolumn{2}{|c|}{$Z=0.44$} & & ns & \multicolumn{2}{|c|}{$Z=-0.61$} & & ns & $\begin{array}{l}\delta^{13} \mathrm{C} U . \text { arcuata }=U . \text { lactea } \\
\delta^{34} \mathrm{~S} U . \text { arcuata }=U . \text { lactea }\end{array}$ \\
\hline Site & 1 & 91.09 & 111.18 & ${ }^{* *}$ & 1 & 9.24 & 5.23 & ns & $\delta^{13} \mathrm{C}$ River $>$ Creek \\
\hline Error term & 13 & 0.82 & & & 7 & 1.77 & & & $\delta^{34} \mathrm{~S}$ Creek = River \\
\hline
\end{tabular}


the Tanshui mangrove estuary, even though the background sediments encode a spatially homogeneous $\delta^{13} \mathrm{C}$ signal derived mainly from mangroves and/or terrestrial C3 plants. The present results also reveal that the structure of the benthic food web can vary greatly from place to place within an estuarine system.

In terms of habitat diversity, spatially different patterns of sedimentary granulometry and infaunal community structure have also been found at the same sites in the Tanshui estuary (Hsieh 1995). From the aspect of food supply, different food types may exist in different microhabitats. Data from salt marsh systems have shown that benthic microalgae are important to food webs in non-vegetated flats and become less available on marsh surfaces where shading by macrophytes is severe (Wainright et al. 2000). In addition, transport of vascular plant detritus and algal production within estuarine systems correlate with tidal mixing processes, which are site specific (Deegan \& Garritt 1997). In the Tanshui estuary, deposit feeders such as nereids and fiddler crabs have different microhabitats which are characterized by a mixture of different foods at different sites; however, the suspension-feeding sabellids have a single type of habitat because they feed on water column POM, which deviates little between sites. Taken together, these data show that this mangrove estuary is biologically diverse, in spite of the fact that the estuary is physically connected as a whole by a network of tidal channels and is predominantly vegetated by the mangrove species Kandelia candel.

Substantial spatial heterogeneity in consumers' $\delta^{13} \mathrm{C}$ has been documented in various salt marshes and estuarine mangrove swamps (e.g. Rodelli et al. 1984, Peterson \& Howarth 1987, Deegan \& Garritt 1997, Wainright et al. 2000). Mechanisms that cause such spatial patterns can vary from system to system and act through both physical and biological processes. Physical processes correlate with flow regime, whereas biological processes involve utilization and digestibility of food sources, opportunism and variability of consumers' feeding habits, and interactions among trophic components. These are discussed below.

\section{Utilization of food sources by polychaetes}

Water column POM constitutes the main food item consumed by the sabellid Laonome albicingillum whereas both water column POM and benthic microalgae (primarily diatoms) are utilized by the nereid Neanthes glandicincta depending on where it resides. A recent study on the $\delta^{15} \mathrm{~N}$ signatures of these 2 polychaete species also supports these assimilations in which the $\delta^{15} \mathrm{~N}$ values of these worms ranged from 2.5 to $4 \%$ o (H. L. Hsieh unpubl. data), indicating they are at a low trophic level as primary consumers $\left(\delta^{15} \mathrm{~N}<\right.$ $9 \%$, Peterson \& Howarth 1987). Nevertheless, by using their large jaws, some of the nereids, such as Neanthes japonica, can even scavenge pieces of animal tissues or other live worms (Tsuchiya \& Kurihara 1979, Fong 1987). Feeding on benthic diatoms or as a mixture with other animal materials can give the nereids a more enriched $\delta^{13} \mathrm{C}$ signature when compared with that of the sabellids.

\section{Physical effects of flow regimes on food availability to polychaetes}

The spatial trend of $\delta^{13} \mathrm{C}$ variability between sites in the nereids and the sabellids is reversed. This inconsistency may be related to their specific feeding modes and to food availability as mediated through local hydrodynamics. Tidal amplitude and hydrology have been proposed to be key factors regulating sulfurnutrient chemistry (Stribling et al. 1998), the relative production, and relative availability of various primary producers in some salt marsh environments (Deegan \& Garritt 1997, Wainright et al. 2000). In addition, hydrological processes control particle feeding by influencing the motions of particulates (e.g. Rhoads \& Young 1970, Jumars \& Nowell 1984).

Previous studies on sediment granulometry revealed that hydrological conditions at the Creek site favor deposition and bedload transportation, whereas those at the River site favor deposition and resuspension (Hsieh 1995, Hsieh \& Hsu 1999). Consequently, under the flow regime at the Creek site, nereids will have more chances to access ${ }^{13} \mathrm{C}$-enriched benthic diatoms $(-19.3 \%)$ due to the particles (diatom associated) being transported more frequently as bedload. However, at the River site, filamentous cyanobacteria or benthic diatoms are less likely to be transported as rolling particles due to the greater consolidation produced by a high content of silt and clay present in the sediments at this site (Hsieh 1995, Hsieh \& Hsu 1999). Thus, the food mostly available to River nereids might originate as deposition from the overlying water. This would give the nereids a lighter $\delta^{13} \mathrm{C}$ signature. It is also possible, although speculative, that fewer benthic diatoms are produced at the River site, resulting in ${ }^{13} \mathrm{C}$-enriched benthic microalgae being less available to a deposit feeder.

By contrast, in the case of the sabellids, flow conditions at the Creek site do not favor resuspension, and thus benthic diatoms are less available in suspension. Therefore, sabellids at the Creek site derive their food mainly from water column POM. Regarding the hydrological characteristics at the River site, the flow rate is slower but the tidal amplitude is greater, so diatoms 
growing on bottom sediments can be lifted into the water column and thus contribute to suspension feeding. Studies on the phytoplankton community of the Tanshui estuary also indicate the occurrence of benthic diatoms, mainly species of Cyclotella and Nitzschia, in the water column (Wu 1999). These diatoms are motile, thus can be easily suspended (Round 1971). As a consequence, food consisting of water column POM mixed with diatoms results in a heavier $\delta^{13} \mathrm{C}$ signature in River sabellids than in their Creek counterparts.

\section{Utilization of benthic microalgae by fiddler crabs at the Creek site}

In the present study, $\delta^{34} \mathrm{~S}$ values of water column POM and benthic microalgae were not determined. However, if the mean value of $9.8 \%$ reported for benthic microalgae in the literature (Currin et al. 1995) is cited for the present study, the enriched sulfur signatures found in crabs and polychaetes at the Creek site would most likely be derived from benthic diatoms (Fig. 2). Benthic diatoms, as anticipated by their easy digestibility and better food quality (e.g. Newell \& Langdon 1986), are indeed an important food source utilized by fiddler crabs living at the Creek site.

\section{Utilization of a C4 vascular plant by fiddler crabs at the River site}

Fractionation in the $\delta^{13} \mathrm{C}$ and $\delta^{34} \mathrm{~S}$ values of the $3 U_{C a}$ crabs is much greater in the River than in the Creek crab assemblages. We suspect that this between-site discrepancy, to a large extent, is attributable to utilization of organic matter derived from the $\mathrm{C} 4$ plant cogon grass Imperata cylindrica by $U$. arcuata and U. lactea living at the River site. In the literature, organic matter derived from vascular plants, such as mangroves and salt marsh Spartina and Arthrocnemum, are also found to serve as food for estuarine invertebrates and fishes (e.g. Haines \& Montague 1979, Fry \& Sherr 1984, Rodelli et al. 1984, Peterson et al. 1986, Wolfrath 1992, Currin et al. 1995, Stribling \& Cornwell 1997).

Studies on the digestion of cellulose in bivalves, polychaetes, and shrimp have demonstrated that the assimilation efficiency of refractory detrital materials from vascular plants is generally quite low (Tenore \& Hanson 1980, Crosby 1985), but it can be increased significantly by microbial colonization of the detritus (Langdon \& Newell 1990). We think that a similar mechanism involving microbial decomposition of cogon grass may also take place in the case of Uca arcuata and $U$. lactea. Understanding how the fiddler crabs can physiologically deal with less labile detritus is im- portant, as this assists our understanding of the role these crabs play in transferring organic matter from a relatively indigestible form to one that becomes accessible to higher trophic levels, such as fish and birds, in this estuary. This subject is worthy of a thorough study.

Furthermore, the possibility cannot be ruled out that the enriched $\delta^{13} \mathrm{C}$ signatures seen in Uca arcuata and $U$. lactea at the River site may result from feeding on trophic intermediaries, such as live meiofauna and carcasses. This is not an uncommon feeding habit in some fiddler crabs (Robertson et al. 1981, Hoffman et al. 1984, Wolfrath 1992). However, we think such a diet is less likely here, at least in the case of $U$. lactea because this species is situated at a low trophic position $\left(\delta^{15} \mathrm{~N}\right.$ : $1.5 \%$, H. L. Hsieh unpubl. data).

Alternatively, these 2 Uca species may feed on benthic microalgae and filamentous cyanobacteria. However, based on $\delta^{13} \mathrm{C}$ signatures, these 2 sources are also less likely because such assimilation would result in the $\delta^{13} \mathrm{C}$ of the fiddler crabs being enriched by about 1 to $2 \%$, a difference too small to explain the approximately $4 \%$ enhancement as expected from assimilation of algal materials (mean: $-19.4 \%$ ) by crabs $(-15.2$ to $-14.9 \%$ ).

\section{Opportunistic dietary choice in polychaetes and fiddler crabs}

In this study, opportunistic dietary choice is best seen in the fiddler crab Uca arcuata and the nereid, and to a lesser extent, in the sabellid (Fig. 2). This phenomenon is consistent with the general concept that consumers rely most heavily on what is produced from local sources (e.g. Peterson et al. 1985, Deegan \& Garritt 1997). Opportunism of dietary choice further characterizes the spatial complexity of benthic organic matter flows in the Tanshui estuary.

\section{Feeding of grapsid crabs}

The grapsid crab Helice formosensis uses a very different food source from the fiddler crabs. This crab feeds upon polychaete sabellids, and thus is a carnivore. The fact that the $\delta^{15} \mathrm{~N}$ signature of this crab is 3 to $7 \%$ more enriched than that of the sabellids (5.5 to $9.5 \%$ vs $2.5 \%$, H. L. Hsieh unpubl. data) also supports such a prey-predator relationship.

\section{Spatial differences in trophic interactions}

The concept that a wide range of $\delta^{13} \mathrm{C}$ values in consumers implies that assimilation of a great variety of 
food sources is based on comparisons of food web structures between habitats along a large spatial gradient, for instance, from estuary to offshore (Rodelli et al. 1984, Peterson \& Howarth 1987). However, results from the present study demonstrate that while polychaetes and crabs at the River site show wider ranges of $\delta^{13} \mathrm{C}$ and $\delta^{34} \mathrm{~S}$, their food sources and trophic interactions with each other are simpler as compared with those at the Creek site which has narrower ranges (see $\delta^{13} \mathrm{C}$ and $\delta^{34} \mathrm{~S}$ ranges in 'Results'). At the River site, water column POM and cogon grass are the 2 major food sources and the macrobenthos are primary consumers. By contrast, at the Creek site, in addition to POM and benthic algae, an animal source is also used, and thus the macrobenthos are comprised of both primary and secondary consumers. Thereby, 'the $\delta^{13} \mathrm{C}$ range' alone can not provide a complete understanding of the variability of food sources, nor even the complexity of trophic relationships between consumers and the pathways of utilizing organic matter.

Why does a more simply structured food web occur at river but not at creek habitats? Possible explanations are given as follows. First, at both sites, crabs are distributed in the higher intertidal zone, whereas sabellids live in the low interital zone. The downshore distance on the mud flat is much shorter at the Creek than at the River site, allowing the grapsid crabs to more easily access their prey, the sabellids. Second, the slope of the mud flat at the Creek site is gentler, resulting in sediment substrates being covered with water for longer time periods during ebbing tides. This situation lengthens the time that sabellids stay in the shallow, upper layers of the sediment; they will even extend their branchial crown out of their tube openings after the tide retreats $(\mathrm{H}$. L. Hsieh pers. obs.), thus benefiting predation by crabs. Third, while the surface area of the intertidal flat at the Creek site is smaller, this locality is more protected from physically harsh conditions (as in the 'Introduction'), and populations of deposit feeders are denser (Hsieh 1995). It is likely that there is competition for the consumption of benthic microalgae between deposit feeders in creek localities, and feeding shifts to carnivory may reduce competition. Furthermore, the intertidal flat at the River site is subjected to influences of tides, waves, and wind action, producing an environment which may not favor intertidally predacious foraging, thus precluding the predatory grapsids from this site.

Acknowledgements. The authors thank Dr C. L. Liu at Illinois State Geological Survey for commenting on measurements of stable sulfur isotopes. The authors also thank P. J. Liu for his assistance in field collection and the laboratory preparation.

\section{LITERATURE CITED}

ASTM Annual book of standards (1974) Gaseous fuels; coals and coke; Atmospheric analysis, Part 26. American Society for Testing and Materials, Philadelphia

Chiu CY, Chou CH (1991) The distribution and influence of heavy metals in mangrove forests of the Tanshui estuary in Taiwan. Soil Sci Plant Nutr 37(4):659-669

Chou CH, Bi CC (1990) Dynamic distribution of nutrients and variation of environmental factors in Tanshui estuary ecosystem. Proc Natl Sci Counc B ROC 14(3):131-141

Crosby MP (1985) The use of a rapid radiolabeling method for measuring ingestion rates of detritivores. J Exp Mar Biol Ecol 93:273-283

Currin CA, Newell SY, Paerl HW (1995) The role of standing dead Spartina alterniflora and benthic microalgae in salt marsh food webs: considerations based on multiple stable isotope analysis. Mar Ecol Prog Ser 121:99-116

Deegan LA, Garritt RH (1997) Evidence for spatial variability in estuarine food webs. Mar Ecol Prog Ser 147:31-47

Fauchald K, Jumars PA (1979) The diet of worms: a study of polychaete feeding guilds. Oceanogr Mar Biol Annu Rev 17:193-284

Fong PP (1987) Particle size utilization in the introduced polychaete Neanthes succinea in San Francisco Bay. Pac Sci 41:37-43

France RL (1995) Carbon-13 enrichment in benthic compared to planktonic algae: foodweb implications. Mar Ecol Prog Ser 124:307-312

France R (1998) Estimating the assimilation of mangrove detritus by fiddler crabs in Laguna Joyuda, Puerto Rico, using dual stable isotopes. J Trop Ecol 14:413-425

Fry B, Sherr EB (1984) $\delta^{13} \mathrm{C}$ measurements as indicators of carbon flow in marine and freshwater ecosystems. Contrib Mar Sci 27:13-47

Haines EB, Montague CL (1979) Food sources of estuarine invertebrates analyzed using ${ }^{13} \mathrm{C} /{ }^{12} \mathrm{C}$ ratios. Ecology $60(1)$ : $48-56$

Hentschel BT (1998) Intraspecific variations in $\delta^{13} \mathrm{C}$ indicate ontogenetic diet changes in deposit-feeding polychaetes. Ecology 79(4):1357-1370

Hicks CR (1982) Fundamental concepts in the design of experiments. CBS College Publishing, New York

Hoffman JA, Katz J, Bertness MD (1984) Fiddler crab depositfeeding and meiofaunal abundance in salt marsh habitats. J Exp Mar Biol Ecol 82:161-174

Hsieh HL (1995) Spatial and temporal patterns of polychaete communities in a subtropical mangrove swamp: influences of sediment and microhabitat. Mar Ecol Prog Ser 127:157-167

Hsieh HL, Hsu CF (1999) Differential recruitment of annelids onto tidal elevations in an estuarine mud flat. Mar Ecol Prog Ser 177:93-102

Hsieh YP, Shieh YN (1997) Analysis of reduced inorganic sulfur by diffusion methods: improved apparatus and evaluation for sulfur isotopic studies. Chem Geol 137: 255-261

Hsieh YP, Yang CH (1989) Diffusion methods for the determination of reduced inorganic sulfur species in sediments. Limnol Oceanogr 34:1126-1130

Hsieh HL, Kao WY, Chen CP, Liu PJ (2000) Detrital flows through the feeding pathway of the oyster (Crassostrea gigas) in a tropical shallow lagoon: $\delta^{13} \mathrm{C}$ signals. Mar Biol 136:677-684

Jumars PA, Nowell ARM (1984) Fluid and sediment dynamic effects on marine benthic community structure. Am Zool 24:45-55 
Kao WY, Chang KW (1998) Stable carbon isotope ratio and nutrient contents of the Kandelia candel mangrove populations of different growth forms. Bot Bull Acad Sin 39: 39-45

Kikuchi E, Wada E (1996) Carbon and nitrogen stable isotope ratios of deposit-feeding polychaetes in the Nanakita River Estuary, Japan. Hydrobiologia 321:69-75

Kwak TJ, Zedler JB (1997) Food web analysis of southern California coastal wetlands using multiple stable isotopes. Oecologia 110:262-277

Langdon CJ, Newell RIE (1990) Utilization of detritus and bacteria as food sources by two bivalve suspensionfeeders, the oyster Crassostrea virginica and the mussel Geukensia demissa. Mar Ecol Prog Ser 58:299-310

Macnae W (1968) A general account of the fauna and flora of mangrove swamps and forests in the Indo-West-Pacific region. Adv Mar Biol 6:73-270

Newell RIE, Langdon CJ (1986) Digestion and absorption of refractory carbon from the plant Spartina alterniflora by the oyster Crassostrea virginica. Mar Ecol Prog Ser 34: 105-115

Newell RIE, Marshall N, Sasekumar A, Chong VC (1995) Relative importance of benthic microalgae, phytoplankton, and mangroves as sources of nutrient for penaeid prawns and other coastal invertebrates from Malaysia. Mar Biol 123:595-606

Peterson BJ, Fry B (1987) Stable isotopes in ecosystem studies. Annu Rev Ecol Syst 18:293-320

Peterson BJ, Howarth RW (1987) Sulfur, carbon, and nitrogen isotopes used to trace organic matter flow in the saltmarsh estuaries of Sapelo Island, Georgia. Limnol Oceanogr 32(6):1195-1213

Peterson BJ, Howarth RW, Garritt RH (1985) Multiple stable isotopes used to trace the flow of organic matter in estuarine food webs. Science 227:1361-1363

Peterson BJ, Howarth RW, Garritt RH (1986) Sulfur and carbon isotopes as tracers of salt-marsh organic matter flow. Ecology 67(4):865-874

Rhoads DC, Young DK (1970) The influence of depositfeeding organisms on sediment stability and community trophic structure. J Mar Res 28:150-178

Riera P, Richard P (1996) Isotopic determination of food sources of Crassostrea gigas along a trophic gradient in the estuarine Bay of Marennes-Oleron. Estuar Coast Shelf Sci 42:347-360

Robertson JR, Fudge JA, Vermeer GK (1981) Chemical and live feeding stimulants of the sand fiddler crab, Uca pugilator (Bosc). J Exp Mar Biol Ecol 53:47-64

Rodelli MR, Gearing JN, Gearing PJ, Marshall N, Sasekumar

Editorial responsibility: Otto Kinne (Editor),

Oldendorf/Luhe, Germany
A (1984) Stable isotope ratio as a tracer of mangrove carbon in Malaysian ecosystems. Oecologia 61:326-333

Round FE (1971) Benthic marine diatoms. Oceanogr Mar Biol Annu Rev 9:83-139

SAS Institute (1996) SAS user's guide: statistics. SAS Institute, Cary, NC

Shih JT (1995) Population densities and annual activities of Mictyris brevidactylus (Stimpson, 1858) in the Tanshui mangrove swamp of Northern Taiwan. Zool Stud 34(2): 96-105

Sokal RR, Rohlf FJ (1981) Biometry. WH Freeman and Co, San Francisco

Stribling JM, Cornwell JC (1997) Identification of important primary producers in a Chesapeake Bay tidal creek system using stable isotopes of carbon and sulfur. Estuaries 20(1):77-85

Stribling JM, Cornwell JC, Currin C (1998) Variability of stable sulfur isotopic ratios in Spartina alterniflora. Mar Ecol Prog Ser 166:73-81

Sullivan MJ, Moncreiff CA (1990) Edaphic algae are an important component of salt marsh food-webs: evidence from multiple stable isotope analyses. Mar Ecol Prog Ser 62:149-159

Tenore KR, Hanson RB (1980) Availability of detritus of different types and ages to a polychaete macroconsumer, Capitella capitata. Limnol Oceanogr 25(3):553-558

Tsuchiya M, Kurihara Y (1979) The feeding habits and food sources of the deposit-feeding polychaete, Neathes japonica (Izuka). J Exp Mar Biol Ecol 36:79-89

Wainright SC, Weinstein MP, Able KW, Currin CA (2000) Relative importance of benthic microalgae, phytoplankton and the detritus of smooth cordgrass Spartina alterniflora and the common reed Phragmites australis to brackishmarsh food webs. Mar Ecol Prog Ser 200:77-91

Wilson RS (2000) Family Nereididae. In: Beesley PL, Ross GJB, Glasby CJ (eds) Polychaetes and allies: the southern synthesis. Fauna of Australia, Vol. 4A, Polychaeta, Myzostomida, Pogonophora, Echiura, Sipuncula. CSIRO Publishing, Melbourne, p 138-141

Wolfrath B (1992) Field experiments on feeding of European fiddler crab Uca tangeri. Mar Ecol Prog Ser 90:39-43

Wu JT (1999) A generic index of diatom assemblages as bioindicator of pollution in the Keelung River of Taiwan. Hydrobiologia 397:79-87

Yanagisawa F, Sakai H (1983) Thermal decomposition of barium sulfate-vanadium pentaoxide-silica glass mixtures for preparation of sulfur dioxide in sulfur isotope ratio measurement. Anal Chem 55:985-987

Zar JH (1984) Biostatistical analysis. Prentice-Hall, New York

Submitted: October 26, 2000, Accepted: July 5, 2001

Proofs received from author(s): January 31, 2002 